Journal of Social and Development Sciences

Vol. 3, No. 6, pp. 184-193, June 2012 (ISSN 2221-1152)

\title{
Relevancy of Corporate Financial Policies and the Profit Maximization View of Islamic Banks
}

\author{
John Taskinsoy \\ Universiti Malaysia, Sarawak-UNIMAS, Malaysia \\ jtaskinsoy@feb.unimas.my
}

\begin{abstract}
This paper examines relevancy of corporate financial policies and documents similarities and/or differences of how profit maximization goal is viewed by Islamic banking institutions (IBIs). Management of the firm is ultimately responsible for maximizing profits and increasing shareholder value, however this challenging task may get plagued by agency problems as well corporate financial policy conflicts. Agency problem is real and it is assumed to occur in most companies worldwide. However, the theory's controversial nature and its narrow focus have not really convinced many scholars whether agency theory in fact provides any broad benefits to firm's stakeholders or not. Scholars seem to be divided into two camps on agency theory. Some authors think that agency theory pays too much attention to short-term goal of share price valuation and it hardly provides any real answers to firm's real problems. On the other hand, some proponents of this theory believe agency theory's useful impact on capital markets.
\end{abstract}

\section{Keywords: Agency problem, IBIs, profit maximization, and corporate financial policies}

\section{Introduction}

In very basic terms, finance can be defined as management of monetary funds; such as money or/and other valuable securities which can be converted into money easily. These funds are necessary resources (means of production) procured and utilized effectively by management to address various business concerns. Financial manager, who is an important and integral part of this whole process, must set clear financial objectives which may be in very broad sense the goals of profit maximization in the short-term and maximization of shareholder value in the long run. Management's decision of how financial assets of the firm ${ }^{1}$ is going to be used will naturally concern shareholders, this is often when agency problem is experienced because shareholders feel that there is a concern of misalignment of objectives (bridge of contractual agreement on management part). Most economics books define agency problem as conflict of interest between principal (shareholder) and agent (management, usually CEO), which usually occurs when agent, who is hired and compensated to do what principal desires based on contractual obligation, deviates from that and pursues own objectives to drive perquisites through investment of financial resources that belong to the firm. The purposes of this paper are to analyze and show how corporate financial policies are used in regards to profit maximization goal and to indicate ways in which conventional banks and Islamic banks are similar or different. The paper is organized around three questions: (1) is agency problem with regard to conventional banks relevant for Islamic banks? (2) Do corporate financial policies govern management's actions in Islamic banks the same way as they do in conventional banks? (3) Do Islamic banks view the goal of profit maximization in the same way as conventional banks do? It should make no difference whether conventional or Islamic, the main goal of any economic activity by a business venture ought to concentrate around maximizing profits in the short-term, increasing shareholder value in the long-term, and building and sharing sustainable future growth with its stakeholders; the only thing that may seem different between conventional and Islamic financial institutions is how each business style actually goes about achieving the goal of profit maximization and what corporate financial policies are in place to govern management's actions to prevent agency problems. What goes on in a firm, directly or indirectly, is in so many ways related to making profits. In most microeconomic courses or in their textbooks, a firm's main goal is often described as maximizing its profits; however, it is often unclear over what time period firms are actually supposed to accomplish this challenging task.

${ }^{1}$ 'Firm' is used to indicate all business types; conventional, Islamic, government, profit, or non-profit. 
In today's modern business world, it would be nearly impossible for any person or any company irrelevant of its business form (sole proprietorship, partnership, corporation), size (small-medium enterprises known as SMEs or large multi-national companies), and volume (annual revenue of thousands, millions, or billions) to bypass various financial products and services offered by banks or other financial institutions to participate in the economic activity which often requires certain financing instruments to be used; as a result, the larger part of any country's (developed, developing, or underdeveloped) total economic activity therefore revolves around different types of financial institutions such as banks (federal reserve banks, commercial banks, and savings banks), savings and loan associations, credit unions, insurance companies, investment banks, mortgage companies, and government lending institutions which try to help consumers and businesses to meet their critical financing obligations; personal, business, or both. For various reasons (mainly religious) Muslim people in most Islamic countries have managed to avoid dealing with conventional banks as long as possible; but as economies in some of these major oil producing and exporting Muslim states especially in the Middle East region, then in Indonesia and Malaysia have grown in an accelerating rate within the last two decades or so, which made it apparent that there was an urgent need and necessity for establishment of Islamic banks that would be in compliance with the principles of Shariah ${ }^{2}$ (Islamic Law) also called fiqh muamalat (Islamic rules on transactions) into the conventional banking system as a start. The rules of Shariah mainly come from two sources; (1) the primary sources, which are the Quran, the Hadith, and the Sunnah; and (2) the secondary sources, such as Shariah scholars (ijma), analogy (qiyas), and personal reasoning (ijtihad). There is no doubt that the introduction of Islamic banking institutions (IBIs) into the conventional banking system (CBS) was an excellent idea, especially when you think about millions of Muslim customers worldwide (currently estimated 1.7 billion Muslims) who have not been using conventional banks' financial instruments mainly because these banks have posed nonconformity (transactions are based on interest) to their religious beliefs in which interest $(\mathrm{riba})^{3}$ is clearly forbidden. Solé (2007) perfectly explained some of the challenging issues related to the rapid expansion of Islamic finance into the conventional banking system and he rightly suggested how policymakers and practitioners need to become acquainted with the overall process and its implications for financial supervision.

According to Solé (2007), Islamic finance is still uncharted territory for most practitioners and policy-makers especially when the current trends indicate that Islamic banking will continue to increase its penetration of conventional financial systems. When you think about it, the whole idea of Islamic banking is so new compared to conventional banking, but it is still an amazingly fast developing phenomenon which has greatly surprised many professionals in financial markets as well as some economists worldwide. Between late 1960s and early 1980s, the world has seen emergence of Islamic banking implementation trials; first started in the Middle East region, then extended its rapid influence into other parts of the globe such as in Asia-Pacific (Malaysia, Indonesia, Philippines), and in Africa (Sudan). The early forms of most Islamic banks' business model was explicitly based on interest free safe-keeping (wadiah) service and some trading activities based on profit-loss sharing where assets (money in savings accounts) from customer deposits were used to engage in various trades and in return any realized profits were shared between banks and their account holders. These banks were not commercial banks as we know today and they certainly did not charge or pay out interest (riba) to their customers as this was clearly forbidden by the Quran ${ }^{4}$. Various forms of Islamic banks had to first co-exist in parallel alongside the conventional banks in their introduction stages, but as their penetration and resilience into the modern financial system has gained speed and robustness in later years, some of these surviving and strong banks have transformed themselves to convert into full-fledged Islamic commercial banks. Today, we see only two countries where the whole banking system is one hundred per cent Islamized; Iran and Pakistan are the early achievers of this type, and Sudan is following their blueprint to accomplish the same. All parties involved in the conventional financial system would probably agree that return on investment expressed as in interest rate is the driving force behind majority of economic activity.

\footnotetext{
${ }^{2}$ Principles of Shariah can be viewed at, AAOIFI - Accounting and Auditing Organization for Islamic Financial Institutions, and IFSB Islamic Financial Services Board.

${ }^{3}$ Yusuf 'Ali (1991) (as cited in Al-Gamal, 2000) provides an excellent translation of the verses (2:278-279]: 278. 0 ye who believe! Fear Allah, and give up what remains of your demand for usury, if ye are Indeed believers. 279. If ye do not, take notice of war from Allah and His Messenger: but if ye turn back, ye shall have your capital sums; Deal not unjustly, and ye shall not be dealt with unjustly.

${ }^{4}$ The Quran clearly prohibits all Muslims against: acceptance or payment of riba (interest); gharar and maisir (contractual uncertainty and gambling); buying, selling, or investing in haram considered products or their companies (alcohol, pornography, and pork).
} 
As a simple analogy; banks, as the driving force of this whole economic process, make their profits based on how effectively they manage the money deposited by customers in savings accounts, and how efficiently they lend the money to other customers as in loans. Now the hard part comes, banks must do an excellent job in attracting customers in highly competitive financial markets to open savings accounts. For banks, in order to attract and convince customers to open an account, they must offer customers a convincing rate of return (interest rate) so that potential customers would postpone their current purchasing decisions to put their money in the bank.

The rate of return expressed as interest rate is the convincing reward for delaying current purchase decisions or not placing the money under the mattress (as expressed in some cultures). However, just because Islam prohibits usury for all Muslims taking in or giving out interest ( $r i b a$ ), people should make no mistake thinking that capital comes at free of charge in Islamic banking. In place of interest charge, Islamic banks have successfully introduced a number of innovative products and services based on profit-loss sharing such as; (PLS) accounts (Mudaraba); mark-up or cost-plus (Murabaha) accounts and joint-venture (Musharaka) accounts. Commonly used other products include: wadiah (like a savings account), bai' bithaman ajil (deferred payment sale), ijarah thumma bai' (hire purchase - usually for motor vehicle purchases), wakalah (agency), qard (interest-free loan), and hibah (gift under wadiah accounts). Solé (2007) claimed that Islamic banking has been experiencing growth rates of 10-15 percent annually for several years, and has been penetrating into conventional financial systems at such a rapid pace that IBIs are now present in close to 60 countries. According to a study conducted by PCW - Price Waterhouse Coopers (May 2009), the total Islamic banking sector in Malaysia by asset size has reached an amazing RM203 billion (US \$58 billion). The first Islamic bank ${ }^{5}$ in Malaysia was established nearly 30 years ago, the progress so far has been astounding and now one of every three banks in Malaysia is an Islamic bank and almost all conventional banks have windows where Shariah compliant Islamic transactions are performed. Today, there are close to 500 Islamic banks worldwide with assets and deposits are estimated to reach \$1 trillion dollar mark by the end of 2012 (currently close to $\$ 900$ billion dollars). Islamic banking has been traditionally concentrated in countries where Muslim population is a majority, but now some conventional banks located in countries where Muslim population is a small minority have been considering opening windows or branches to enable Muslim customers to enjoy various banking transactions (e.g., USA, UK, and Japan).

Just in US alone, last decade has seen its good share of corporate misconduct ${ }^{6}$; incompetent financial managers; inefficient regulatory system; and finally, but not the least, insufficient judiciary process to punish those corporate executives who have committed fraudulent ${ }^{7}$ and criminal acts ${ }^{8}$. These, along with other factors not mentioned here, largely contributed to the 2001 crises plus the most recent global financial meltdown of 2008 which IMF called it as 'the largest financial shock since Great Depression.' Probably it is a good idea to mention that a financial crisis, unlike an environmental crisis (e.g., earthquake), would take some time to develop and they would not suddenly occur without signaling any prior warning signs indicating that something big is likely to happen unless policy makers take some actions to change the course of economy in question. Prior to crisis, a TV personality in USA called it an economic 'Armageddon' on air on August 1, 2007 and accused the Fed not taking any actions. By September 2007, financial crisis made its way to Europe where Britain's Northern Rock bank got emergency support from the bank of England showing signs of weakening deposits. Finally, former Fed Chairman Alan Greenspan warned of "large, double-digit declines" in home values (Kuhnhenn, 2010). After the 2008 financial crisis lost some steam and finally stabilized, nonetheless it has left behind staggering millions of people without jobs; thousands of failed businesses; tens of millions of people with washed-away life savings; and not surprisingly, deeply shaken investor confidence

\footnotetext{
${ }^{5}$ Establishment of the first Islamic bank in Malaysia (Bank Islam Malaysia - BIMB) was in 1983 but the earlier developments can be traced all the way back to 1963 when Muslim Pilgrims Savings Corporation was set up.

${ }^{6}$ Accounting scandals of some big name US corporations as follow: Nortel Networks, Bristol-Myers Squibb, HealthSouth, Global Crossing, Fannie Mae, Tyco International, WorldCom, Rite Aid, Peregrine Systems, Halliburton, AOL Time Warner, and many more (investors lost billions of dollars).

${ }^{7}$ See bankruptcy filings of Enron (little over $\$ 63$ billion dollars); WorldCom (over $\$ 100$ billion dollars); and Global Crossing (nearly $\$ 50$ billion dollars).

${ }^{8}$ Enron CEO Jeff Skilling was sentenced to 24 years in prison; and WorldCom CEO Bernard Ebbers received a sentence of 25 years of imprisonment.
} 
in the whole financial system. It would probably be an enormous task or maybe even an impossible one to calculate the total financial damage caused by this recent global financial melt-down, but I seriously think that this enormous financial disaster left behind a clausal worldwide financial loss that could be as much as two trillion dollars, or even more. It was time to start the clean-up work, of course politicians wasted no time to introduce some drastic measures in Washington in an attempt to gain back the badly damaged investor confidence and hopefully have public support on their side. A number of promising Wall Street reforms were introduced some of which were signed into law to ensure that the US financial system going forward will achieve at least the following four main objectives; (1) more transparency, (2) true accountability, (3) greater ability to forecast future crisis, and (4) trustworthy and well-functioning regulatory system to avoid financial losses for the tax payers.

\section{Review of the Main Concepts}

Agency Problem: Agency problem is defined as conflict of interest between principal and agent, which usually occurs when agent, who is hired and compensated to do what principal desires based on contractual obligation, decides to deviate from that and pursue own objectives to drive perquisites through excessive investment of financial resources that actually belong to the firm. Fama and Jensen (1983) point out that firms' survival critically depends on how well agency problem is controlled. According to Eisenhardt (1988), "the domain of agency theory is relationships that mirror the basic agency structure of a principal and an agent who are engaged in cooperative behavior, but have differing goals and differing attitudes toward risk" (p. 59). Berle and Means (1932) believed that many firms are in fact controlled by managers rather than owners. Baumol (1959) and Williamson (1981) suggested that managers have control of the firm and may pursue own objectives other than profit maximization. Stulz (1990) claimed that management drives perquisites from investments and invests as much as possible even if it means investing in negative present value (NPV) projects. Jensen (1986) along the same line argues that free cash flow after positive NVP projects creates much needed incentive for the management to overinvest. Another similar analogy is made by Stulz (1990) that management is always motivated and ambitious to invest if there is surplus in cash flow after the firm's positive NVP projects. Jensen and Meckling (1976) believed that additional cash the firm is holding may provide needed funds for managers to invest in projects that offer non-pecuniary benefits but destroy shareholder value. Eisenhardt (1988) suggests that "the heart of principal-agent theory is the trade-off between (a) the cost of measuring behavior and (b) the cost of measuring outcomes and transferring risk to the agent" (p. 61). When agent's contractual obligation requires enforcement by principal as a result of agency problem, this could mean very high transaction cost known as agency cost to the firm. But not all agents produce agency problems, those who perform well with consistency and meet their obligations satisfactorily need to be rewarded with a combination of material, moral, or coercive incentives to avoid future agency problems. Is agency problem with regard to conventional banks relevant for Islamic banks? Agency problem is real and probably occurs in many companies worldwide irrelevant of business type whether conventional or Islamic. Effective regulatory system is crucial for the financial industry. Eisenbeis (2004) argues that financial system can in fact get plagued by agency problems as well as goal conflicts between various regulatory agency bodies ${ }^{9}$.

Eisenbeis (2004) also believe that goal conflicts of several regulatory agencies along with agency problems are the main contributors to 2001 and 2008 financial crises. When we look at the most recent global financial meltdown, we certainly see that agency problems and inefficient financial regulatory system have existed not just in US alone, but also similar situation existed in most European countries plus to a certain degree the rest of the world as well. Although IBIs in Islamic countries seem to have more religious reasons ${ }^{10,11}$ not to get engaged in any unethical business conduct, however agency problems still tend to occur in IBIs just the same

\footnotetext{
${ }^{9}$ US Congress is the main authority, but it assigns goals and responsibilities to three financial regulators; OCC - the Office of the Comptroller of the Currency (OCC), Fed - the Federal Reserve System and FDIC - Federal Deposit Insurance Corporation.

${ }^{10}$ Prophet Muhammad s.a.w said that: "If you guarantee me six things on your part, I shall guarantee you paradise: Speak the truth when you talk, keep a promise when you make, when you are trusted with something fulfill your trust, avoid sexual immorality, lower your eyes and restrain your hand from injustice" (Hadith)

${ }^{11}$ Prophet Muhammad s.a.w also said, "There is a piece of flesh in the human body. If this is good, all the organs will be good. If this is evil, all the organs will be evil. This piece of flesh is the heart" (Hadith)
} 
way as they do in conventional banks. Besides, most Islamic countries are still in developing-country status which makes them quite vulnerable to matters like; insufficient financial regulatory system; ineffective corporate governance; and weak government law enforcement agencies. Sakr (2003) sees major issues in Arab countries that relate to political accountability, inefficient use of public tax money, and insufficient transparency ${ }^{12}$ issues in reporting financial results. Power (1999) stated that transparency is a safeguard against corruption. Nelson (2000) argues that making the public part of the decision-making process will improve transparency and therefore accountability. Agency problems in IBIs may largely come from the two Shariah compliant products: Mudaraba contracts also known as Profit Sharing Investment Accounts (PSIAs) and Musharaka (joint venture). However, most of IBIs now offer various project financing and investment related products through Murabaha (cost plus a previously agreed mark-up). Dar and Presley (2000) claim that "PLS contracts are inherently vulnerable to agency problems as entrepreneurs have disincentives to put in effort and have incentives to report less profit as compared to the self-financing owner-manager" (p. 5). Dar and Presley (2000) also argued that shareholders have limited control rights with Mudaraba type of financing which opens doors for more agency problems.

Relevancy of Corporate Financial Policies: Most corporate executives tend to agree that there is a close and meaningful interface between corporate strategy and corporate financial policy; however in this relationship, it is hard to determine which one is the cause and which one is the effect because the role of each constantly interchanges; sometimes corporate strategy is the cause and the financial policy is the effect, and other times it is vice versa. The importance and the relevancy of corporate financial policies are viewed as critical and most necessary in three main areas of the firm: (1) Capital structure - equity financing versus debt financing, or both. Policy makers of the firm make a decision on what financing mix the capital structure will consist; equity capital, debt capital, or a combination of both. (2) Investments and allocation of certain funds - policies that limit how much management can invest in fixed assets and putting constraints on the use of current assets. Allocation of available funds from one project to another should be based on best possible outcome situation for the firm. (3) Dividend policy - this is not a straight forward decision on firms' part because a good dividend policy decision certainly requires a prior comprehensive analysis of financial needs of the firm in terms of both short-term and long-term goals; investors' preference is also taken into consideration consistent and regular dividend payment by the firm is viewed as positive by investors which may lead to a positive influence on firm's stock price valuation. Lastly, as the owners of the firm, shareholders preference is also considered before a dividend can be set. Modigliani and Miller (1958), and Stiglitz (1969) argued that the firm's financial policy has no consequence in its attempt to achieve profit maximization. Stiglitz (1974) wished to show that besides infrequently occurring special circumstances, corporate financial policies of the firm absolutely had no effect on the valuation of the firm based on the general equilibrium model. Stiglitz (1974) further divided financial decisions into four categories, in each of which "how" and "when" questions were needed to be answered in order to effectively analyze the firm's options and available resources to develop the kinds of corporate financial policies required. These four important categories that Stiglitz (1974) mentioned had to do with; (1) ways in which the firm plans to finance its investments (through equity capital or debt capital); (2) firm's dividend policy describing how the firm plans to distribute its revenue; (3) retained earnings - how much the firm should invest and how much of the earnings should be retained by the firm for future expansion and growth; (4) funds allocation - selection method of projects and technology implementations. Meyer and Kuh's (as cited in Stiglitz, 1974) study indicated that "the correlation between retained earnings and investment does not provide an explanation of the determination of the level of investment" (p. 852).

According to Margsiri and Mello (2011), financial policy of the firm is inseparable from its investment policy. Most CEOs of large companies would agree that one of their top priorities is to manage risk. Risk management requires clear understanding of three critical elements of corporate financial policies; (1) capital structure debt versus equity or a mixture of the two; (2) investment options - deciding what investments would serve

\footnotetext{
12 IFSB's standard on transparency: Transparency or public disclosure of reliable and timely information should enable Profit Sharing Investment Accounts' (PSIA's) assessment of financial conditions and performance, business activities, risk profile and risk management practices of Islamic banks. The standard on transparency and market discipline aims to encourage Islamic banks and regulators to disseminate information that is vital to assist PSIA in their decision making.
} 
the firm's short-term and long-term needs the best; (3) and dividend policy - how much of the revenue will be paid to investors in the form of dividends and how much of the revenue will be retained by the firm for future growth and expansion projects. Competing firms tend to watch each other very closely in order to stay one step ahead of the competition and they are always interested in knowing what the other firm is doing. In fact, they even sometimes change or modify their corporate financial policies in an attempt to respond to the kind of decisions made by the peer firms. Leary and Roberts (2010) argue that some corporate policies such as dividend payments, executive perks, and marketing related strategies are greatly influenced by peer firms. Capital structure of each firm is a different story though because every firm is assumed to choose its capital structure independent of what capital structures peers select or other firms choose in the industry. It would be argued that a firm chooses an appropriate capital structure form that fits its needs the best possible way and besides there is no two firms of exactly identical situation where entirely same capital requirements are at present. According to a survey by Graham and Harvey (2001), nearly twenty five percent of CFOs surveyed identified peer influence in their financial decisions. In the real world, firms' managements usually have information that shareholders do not have, it is called asymmetric information, which makes it difficult for principal to evaluate agent's performance; as a result, agent uses this to his/her advantage to pursue own objectives to drive perquisites as explained earlier. As the 'game theory' would suggest that shareholders use various compensation mechanisms ('the carrot') and control schemes ('the stick') to align management objectives in line with the objectives of principal. Stulz (1990) argued that corporate financial policies could reduce the costs of over and underinvestment especially if management controlled resources were influenced. Corporate financial policies certainly play an important role in firm's SGR (sustainable growth rate). In order to achieve a good SGR, a firm needs to do three things well; (1) select the most appropriate capital structure for the firm and maintain it without issuing new equity unless it is absolutely necessary; (2) set dividend payments and maintain a balanced ratio; and (3) pay close attention to changing market conditions and make necessary adjustments to increase sales or revenue.

All corporate financial policies of IBIs have to follow Shariah principles which are based on Islamic laws. Financial policies covering Shariah-compliant financing (SCF) are thought to be in many ways similar to conventional financing; however there happens to be also some radical differences between the two. For instance, as long as it is within the corporate law and based on acceptable ethical business conduct, there is really no rule preventing conventional banking institutions (CBIs) from investing and earning an honest rate of return on investments (usually expressed as interest rate). Same above conditions are also true in the case of IBIs, meaning investments can be made with expectation of an honest return, as long as this expected rate of return is not expressed as in interest ( $r i b a$ ) which is considered to be usurious and absolutely prohibited by Islamic law. The Quran clearly prohibits all Muslims against: acceptance or payment of riba (interest); gharar and maisir (contractual uncertainty and gambling); buying, selling, or investing in haram considered products or their companies (alcohol, pornography, and pork). There are three important aspects to governance of IBIs; (1) AAOIFI, The Accounting and Auditing Organization for Islamic Financial Institutions, provides international standards on accounting, auditing and corporate governance issues; (2) IFSB, the Islamic Financial Services Board, is in charge of supervision and regulatory related matters; (3) Shariah board that is set up by each IBI to monitor every financial transaction's compliance with Islamic laws. Violation of Islamic law by ordinary Muslims as well as by IBIs would result in a punishment situation. An IBI's violation of Shariah principles would have some severe financial consequences for the business; of course depending on the severity of violation, it can certainly lead to suspension or cancellation of the banking license. A very special and devoted relationship exists between Muslim believers and Allah (swt). Prophet Muhammad s.a.w said that: "If you guarantee me six things on your part, I shall guarantee you paradise: Speak the truth when you talk, keep a promise when you make, when you are trusted with something fulfill your trust, avoid sexual immorality, lower your eyes and restrain your hand from injustice" (Hadith). Islam in a way provides all Muslims an opportunity for self-regulation through teachings of the Quran, the Hadith, and the Sunnah. Prophet Muhammad s.a.w also said, "There is a piece of flesh in the human body. If this is good, all the organs will be good. If this is evil, all the organs will be evil. This piece of flesh is the heart" (Hadith). Besides so many invaluable teachings of the Quran, the Hadith, and the Sunnah, every transaction of IBIs is governed by the Islamic law and no transaction can move forward without the approval of Shariah board in each IBI. The role of Shariah board consisting of religious scholars is not just to monitor compliance related issues of financial transactions in IBIs, but also to provide consultancy and expert opinion in rather complicated financial 
matters. A Shariah board sometimes may provide service to more than one IBI at the same time because; first, establishing a Shariah board is costly and smaller IBIs may not be able to afford to have their own; second, not enough religious scholars around to serve in Shariah board for every IBI. Utilization of the same Shariah board's service by more than one IBI at one time does not pose any privacy concerns because shared information is highly confidential.

Profit Maximization and the View of IBIs: "For nearly a century, the assumption that the firm maximizes profits has been front and center in neoclassical economic theory" (Anderson and Ross, 2005). In most economics text-books and academically written papers on the subject, the mathematical description of profit maximization model is often given as: marginal profit $(\mathrm{M} \pi)$ equals marginal revenue (MR) minus marginal cost (MC). The goal of profit maximization is at the center of all economic activity by the firm irrelevant of its business form whether Islamic or conventional. According to Alchian (1950) "there is no meaningful criterion for selecting the decision that will maximize profits" (p. 212). Alchian (1950) argued that "Realized positive profits, not maximum profits, are the mark of success and viability" (p. 213). Based on this, firms are totally flexible using whatever means in their disposal to achieve this objective of 'positive profits' not 'maximum profits,' and as long as they are successful in their pursuit, it does not really matter what processes they have used or what motivational factors were behind their success. Alchian (1950) also claimed that "this is the criterion by which the economic system selects survivors: those who realize positive profits are the survivors; those who suffer losses disappear (p.213). This is almost the same type of analogy that we would find in "Darwinism" where "survival of the fittest" moves on and the weak ones get pushed out of the competition and left behind to become extinct. In modern business, the competition is so severe and so merciless that there is no room for falling behind to face elimination, therefore conventional or Islamic, all business venture types must quickly adapt to changing market conditions and make decisions fast to take advantage of opportunities in their business environments to prevail against peer firms to maximize profits. Asplundy (2007) claims that profit maximization still remains to be the underlining assumption in modeling firm behavior. Then, the question is; do firms pay attention to what other firms (peers) do trying to maximize profits? Keen and Standish (2008) think that "maximizing profit while ignoring what other firms do is rather like rowing a boat to a specific location while ignoring the wind and tides" (p.2). According to a survey by Graham and Harvey (2001), nearly twenty five percent of CFOs surveyed identified peer influence in their financial decisions. As discussed previously, corporate financial policies, especially policy on firm's capital structure selection, certainly play an important role in firm's SGR (sustainable growth rate). However, it is largely assumed by economists that firms choose their capital structures independent of other firms in the industry. But nonetheless, firms must still be interested to know what other firms do in the industry, and they pay even a closer attention to some peer firms if they are in heated competition with them.

Hirshleifer (as cited in Anderson and Ross, 2005) writes, "According to the classical formulation, the aim of the firm as a decision-making agent is to maximize (economic) profit" (p. 265). Corporate executives and investors would strongly argue that economic incentive of profit maximization is the fundamental reason behind the creation of firms (businesses) in the first place. The idea of maximizing profits is in fact what makes people to decide to engage in certain economic activity (investments), and without this economic incentive in place, it would have been very difficult or almost impossible to convince people to put their money (or other valuable assets) in something or invest on projects where they will receive no return on their investment. According to Coase (1937), firms are made of contracts. Anderson and Ross (2005) argue that firms do not automatically maximize profits under the condition of marginal revenue equaling marginal cost. They insist that decision makers (management) of the firm must consider other factors such as uncertainty, time value of money, and risk to ensure firm's success of achieving maximum profits both in short-term and long-term. Under market selection hypothesis, we can probably assume that all firms are profit-maximizing firms, because if they are not, then they take huge risk of being weeded out of competition as nonprofit- maximizing firms. So, in a way, existing market forces lead firms to either achieve profit maximization goal or face total elimination. Friedman (1953) wrote: "...the process of natural selection thus helps to validate the hypothesis (of profit maximization) or, rather, given natural selection, acceptance of the hypothesis can be based largely on the judgment that it summarizes appropriately the conditions for survival" (p.22). Enke (as cited in Blume and Easley, 2002) who write: "In these instances the economist can make aggregate predictions as if each and every firm knew how to secure maximum long-run profits" (p.96). Ismail 
(2002) proposed that IBIs financing activities should be consistent and more importantly compliant with the Islamic law. His paper argues that under this model, an IBI has a crucial responsibility to its shareholders and account holders which means that social welfare becomes the responsibility of the government not the banks. Under the profit maximization model, all products and services can also be offered by IBIs as long as there is no element of riba involved in any financing offerings. Conventional banks maximize profits amongst other things mainly through buying and selling securities (including currency) and paying or charging an interest rate in the process. Since it is clearly forbidden for Islamic banks to pay or charge interest ( $r i b a)$, then the question of how IBIs actually achieve the goal of maximizing profits comes in the mind.

IBIs achieve profit maximization through fees that they charge for providing services and most of their profit comes from two PLS accounts; Mudaraba (profit sharing) and Musharaka (joint venture). Islamic banking model is not without any criticism; some scholars think that profit maximization theory in IBIs pays too much attention to profit and wealth is distributed unevenly; plus, some banking activities are considered suspicious. A recent IMF study ${ }^{13}$ by (Hasan and Dridi, 2010) agrees that Islamic finance is 'too big to ignore.' The study also points out that ".it is one of the fastest growing segments of the global financial industry." Although Islamic finance is getting close to $\$ 1$ trillion dollars of volume worldwide, which is just remarkable, nonetheless it still has not convinced many scholars and financial professionals around the world that Islamic banks can show enough resilience going forward and manage to focus on overcoming some of the challenges that make Islamic finance still not prone to financial crisis at global scale. In the IMF report, the following points were highlighted; (1) before crisis (2005-2007), Islamic banks were more profitable than conventional banks because they had much smaller portfolios and their Shariah compliant investments were not greatly exposed to the type of 'financial instruments' 14 that adversely affected conventional banks; (2) just prior to crisis (2007-2008), larger Islamic banks still managed to do better than smaller banks due to effective utilization of portfolio diversification. The report also highlighted that Islamic banks' profitability before crisis were not results of high risk taking which suggested that development of Islamic finance industry was achieved to enable some of the larger Islamic banks to compete with conventional banks; (3) Islamic banks were more affected than conventional banks as the crisis hit the real economy in 2009, this is when IBIs saw a very sharp decline in profitability. However, even during the 'deepening impact' of the crisis, Islamic banks achieved higher credit and asset growth which easily doubled those of conventional banks. The success of IBIs in recent decades is an amazing story to tell, but it still does not erase all the concerns, questions, and challenges that the Islamic finance industry is currently facing. All key players, policy makers, politicians, regulatory agencies, and banking professionals who are part of the Islamic financial industry should take this unique opportunity to improve upon things like; establishing effective financial infrastructure; better transparency in financial reporting; well-functioning regulatory system; cooperation with the work of global financial reforms; and creating the right kind of policies to encourage better development of the Islamic banking industry to foster strong future growth.

\section{Methodology}

This research paper began with reviewing previously published academic works in the areas of relevancy of corporate financial policies and the profit maximization view of Islamic financial institutions. The paper is organized around three questions that are particularly important to establishing evidence of how firms maximize profits and how Islamic financial institutions (IBIs) view the goal of profit maximization. The first question asks whether or not agency problem occurs in Islamic banks same way as they do in conventional banks. Ross ${ }^{15}$ (as cited in Eisenhardt, 1988, p. 57) argued that "examples of agency are universal." The second question is; do corporate financial policies govern management's actions in IBIs same way as how they do in conventional banks? The third question is; do Islamic banks view the goal of profit maximization in the same way as conventional banks do?

\footnotetext{
13 "In "The Effects of the Global Crisis on Islamic and Conventional Banks: A Comparative Study," economists Jemma Dridi of the IMF's Middle East and Central Asia Department and Maher Hasan of the IMF's Monetary and Capital Market Department look at the effects of the crisis on bank profitability, credit, and asset growth in countries where both types of banks have a significant market share."

14 Islamic banks were not exposed to sub-prime mortgages as well as derivatives and hedging funds activities as conventional banks did.

15 See Ross, S. (1973, p.134) “The Economic Theory of Agency: The principal's problem.” American Economic Review, 63, 134-139.
} 


\section{Conclusion}

This paper began with looking at two conflicting positions on agency theory - On one hand; a group of authors arguing that agency theory has a narrow focus that pays too much attention to short-term goal of profit maximization and its influence on stock price valuation. Opponents of this theory also claim that agency theory hardly provides any real answers to firm's important problems that need solutions. On the other hand, proponents view agency theory as impactful on highlighting problems related to corporate functioning. Eisenhardt (1988) points out that "a more valid perspective lies in the middle. Agency theory provides a unique, realistic, and empirically testable perspective on problems of cooperative effort" (p. 72). Any type of conflict is viewed by business as a way of potential hazard to firm's performance which may ultimately affect shareholder value negatively. Agency problem is real and firms need to pay a great deal of attention to it because as Fama and Jensen (1983) point out that firms' survival critically depends on how well agency

problem is controlled. The intent of this paper is to shed some light on agency related problems and use of corporate financial policies to influence firm's profit maximization goal. Instead of obsessively focusing on maximizing profits in the short-term, firms need to understand their limitations and select the right set of financial policies accordingly to maximize profits in the short-term as well as increase shareholder value in the long-term. Extensive research on the topic shows no real major difference in profit maximization goal between conventional banks and Islamic banks because both business ventures irrelevant of their different business styles take the objective of maximizing profits very seriously. The most obvious difference separating conventional banks from IBIs is that interest (riba) is the center of all economic activity in conventional financial system, but it is clearly forbidden in Islamic financial system. Another difference between the two banking styles in terms of governance and corporate financial policies is that IBIs must follow Islamic law and all financial policies must comply with the principles of Shariah (Islamic law) in which every transaction of an IBI is monitored by a Shariah board. A recent IMF study by (Hasan and Dridi, 2010) agrees that Islamic finance is 'too big to ignore.' The study also points out that ".it is one of the fastest growing segments of the global financial industry." Islamic banks fared better than conventional banks before and during the most recent global financial crisis of 2008 and the success of IBIs in recent decades is an amazing story to tell, but it still does not erase all the concerns, questions, and challenges that the Islamic finance industry is currently facing. All key players, policy makers, politicians, regulatory agencies, and banking professionals who are part of the Islamic financial industry should take this unique opportunity to improve upon things like; establishing effective financial infrastructure; better transparency in financial reporting; well-functioning regulatory system; cooperation with the work of global financial reforms; and creating the right kind of policies to encourage better development of the Islamic banking industry to foster strong future growth.

\section{References}

Alchian, A. A. (1950). The Journal of Political Economy, 58(3), 211-221.

Anderson, L. \& Ross, L. (2005). The Methodology of Profit Maximization: An Austrian Alternative. The Quarterly Journal of Austrian Economics, 8(4), 31-44.

Asplundy, M. (2007). A Test of Profit Maximization. Royal Institute of Technology.

Berle, S. \& Means, P. (1932). The Modern Corporation and Private Property (2nd edition).

Baumol, W. J. (1959). Business Behavior, Value and Growth. New York: Macmillan.

Blume E. L. \& Easley, D. (2002). Optimality and Natural Selection in Markets. Journal of Economic Theory, 107, 95-135.

Coase, R. (1937). The Nature of the Firm. In The Firm, the Market, and the Law. Chicago University of Chicago Press, 33-55.

Dar, W. \& Presley, V. (2000). Lack of Profit Loss Sharing in Islamic Banking: Management and Control Imbalances. Economic Research Paper No. 00/24. Loughborough University. Eisenbeis, A. (2004). Agency Problems and Goal Conflicts. Working Paper 2004-24.

Eisenhardt, K. (1988). Agency Theory: An Assessment and Review. The Academy of Management Review, 14(1), 57-74. 
Fama, E. \& Jensen, M. (1983).Agency Problems and Residual Claims. Journal of Law and Economics, 26, 327349.

Friedman, M. (1953). Essays in Positive Economics. University of Chicago Press, Chicago.

Graham, J. R. \& Harvey, C. (2001). The Theory and Practice of Corporate Finance: Evidence from the Field. Journal of Financial Economics, 60(2).

Hasan, M. \& Diridi, J. (2010). The Effects of the Global Crisis on Islamic and Conventional Banks: A Comparative Study. IMF report.

Ismail, A. H. (2002). The Deferred Contracts of Exchange: Al-Quran in contrast with the Islamic economist's theory on banking and finance. Kuala Lumpur.

Jensen, M. \& Meckling W. H. (1976). Theory of the Firm: Managerial Behavior, Agency Costs and Ownership Structure. Journal of Financial Economics, 3, 305-360.

Jensen, M. (1986). Agency Costs of Free Cash Flow, Corporate Finance and Takeovers. American Economic Review, 76, 323-329.

Keen, S. \& Standish, R. (2008). Profit Maximization, Industry Structure, and Competition: A Critique of Neoclassical Theory. Elsevier Science.

Kuhnhenn, J. (2010). Senate passes sweeping Wall Street reform. http://www.msnbc.msn.com/id/38258047/38316915.

Leary, M. T. \& Michael, R. R. (2010). Do Peer Firms Affect Corporate Financial Policy? Working Paper.

Margsiri, W. \& Mello, A. S. (2011). Risk Management in Corporate Policy. DBJ Discussion Paper Series, No. 1101.

Modigliani, F. \& Miller, M. H. (1958). The Cost of Capital, Corporation Finance and the Theory of Investment.

The American Economic Review, 48(3), 261-297. URL:http://www.jstor.org/stable/1809766

Nelson, P. (2000). Heroism and ambiguity: NGOs advocacy in international policy. Development in Practice, $3(4)$.

Power, M. (1999). The Audit Society: Rituals of Verification, Oxford University Press, Oxford.

Sakr, N. (2003). Freedom of expression, accountability and development in the Arab region. Journal of Human Development, 4(1), 29-46.

Stiglitz, J. E. (1969). A Re-Examination of the Modigliani-Miller Theorem. The American Economic Review,

59(5), 784-793. URL:http://www.jstor.org/stable/1810676

Stiglitz, J. E. (1974). On the Relevance of Corporate Financial Policy. The American Economic Review, 64(6), 851-866.

Solé, J. (2007). Introducing Islamic Banks into Conventional Banking Systems. IMF Working Paper. WP/07/175.

Stulz, R. (1990). Managerial Discretion and Optimal Financing Policies. Journal of Financial Economics, 26, 327.

Williamson, O. E. (1981). The Economics of Organization: The Transaction Cost Approach. The American Journal of Sociology, 87(3), 548-577.

Yusuf, A. A. (1991). The Meaning of the Holy Qur'an. Brentwood, MD: Amana Corporation.

Accounting and Auditing Organization for Islamic Financial Institutions (AAOIFI) http://www.aaoifi.com/aaoifif/

IFSB - Islamic Financial Services Boardhttp://www.ifsb.org/ 